\title{
Narrativa visual: possibilidades para (co)existir
}

\author{
Marta Facco (UDESC)
}

\section{Link para a narrativa visual:}

https://www youtube.com/watch?v=GkTBI6pV8B0

A presente narrativa visual, intitulada Possibilidades para (co)existir, é parte da pesquisa de Mestrado defendida em junho de 2018 no PPGAV/UDESC, sob a orientação da Profa. Dra. Jociele Lampert, com o título de objeto Epistêmico em travessia.

A narrativa é composta por imagens de minha autoria, mescladas a outras das quais me aproprio, como forma de criar relações de diálogos e ambiguidades ao mesmo tempo. Essas imagens, à medida que vão surgindo, criam um diálogo com seu observador, possibilitando formas paradoxais e díspares de narrar a visualidade proposta. As imagens são escolhidas seguindo critérios não convencionais de composição, mas a cor é um dos elementos que possibilita acionar em mim novos olhares e, consequentemente, memórias sensórias esquecidas. Quando apresento a imagem de uma cadeira fora de seu contexto doméstico, abandonada em um lugar inóspito ou em cima de uma árvore, sugiro olharmos mais demoradamente para ela, propondo assim um desvelar da poética nela impregnada. Despi-la do caráter utilitário para criar outros mundos possíveis para (co)existir, novas formas de relações e inter-relações com o Outro e com o mundo. Fachadas de casas degradadas vão trilhando o caminho por onde o observador deve andar, entre a destruição, o abandono e o descaso.

As imagens da narrativa visual foram selecionadas a partir de afetos e afecções (no sentido de afetar e ser afetado). Elas geravam atravessamentos à medida que eram encontradas. Assim, as relações que estabelecia com essas 


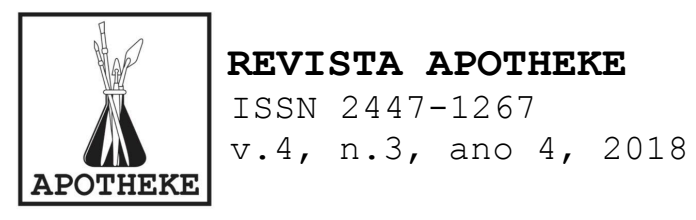

imagens ultrapassavam de uma simples identificação ou afeto; eram como ícones que surgiam formando elos poéticos que expandiam o meu rizoma conceitual, criando um sentido. Sentido este que se configurou em uma visualidade, com um roteiro impregnado de afecções e sentidos contraditórios, pois possibilita múltiplas noções interpretativas.

Ao criar a visualidade, percebi que as imagens selecionadas eram, na verdade, o meu próprio lugar de processo. Pois cada uma poderia se desdobrar em muitas outras coisas, e isso ocasionou um outro processo, o da reflexão sobre as imagens que escolho ou simplesmente me escolhem: a sensibilidade afetiva de uma cor, uma janela de uma casa em ruínas, uma mancha na parede ou uma cadeira jogada ao descaso. o que de poético consigo apreender nessa imagem, e assim furtá-la, que faça com que me interesse por ela? Isso passou a ser algo relevante para pensar em outros desdobramentos dos referidos atravessamentos poéticos.

Assim, narrar passa a ser uma possibilidade de compreensão dos meus processos, através da experiência do ver/olhar/sentir que gera descontinuidades e cria conexões nas teias de conhecimento. Também se pode dizer que a narrativa "é uma forma de compreensão da experiência", pois "possibilita mediações entre pensamento e ação" (MARTINS; TOURINHO, 2009, p. 4), como também nos proporciona um refletir sobre as experiências anteriores e a criação de algo a partir delas.

Contudo, quero crer que as narrativas visuais poderiam ser comparadas a "experiências singulares" (DEWEY, 2010), pois, para construir uma narrativa, suponha que esse indivíduo tenha refletido sobre as experiências estéticas que lhe atravessaram e, a partir delas, obteve singularidades que culminaram em uma determinada visualidade. Essas experiências singulares diferem das experiências ditas reais (comuns no dia a dia) e das experiências estéticas (da qual usamos a percepção como principal ferramenta), pois se trata da união 


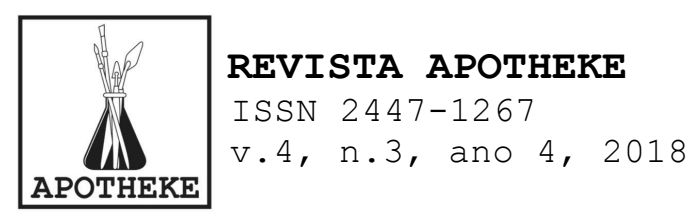

entre percepção e ação ${ }^{1}$. Assim, uma experiência singular, no campo das Artes Visuais, será uma produção de sentidos com qualidade estética e propriedades ímpares, pois advém de um processo individual, com características próprias, apreensões e reflexões significativas do sujeito, que se constroem à medida que também o constroem. A experiência singular pode, então, ser pensada como o resultado da relação entre percepção, apreensão, reflexão e ação, em que "seu encerramento é uma consumação e não uma cessação" (DEWEY, $2010, p .110)$.

Narrar passa a ser mais do que sequenciar imagens ou contar uma história, pois faz parte de um processo de consciência e compreensão das experiências que nos atravessam. É habitar lugares no devir da criação e expandir para um além do pensar. É um pertencimento, um (co)existir mundos impossíveis através das experiências do ver/olhar/sentir que nos possibilitam experiências singulares.

A narrativa visual exibida remonta a uma história de experiências estéticas significativas do processo criativo de inventações $^{2}$ de uma cadeira que se desdobra em inúmeras maneiras, construindo e reconstruindo mundos onde possa (co)existir. Lugares onde o tempo e o espaço são mensuráveis e possibilitam abrir fendas para respiros, intervalos onde habitam esquecimentos e lembranças. O som do ruído ao fundo assenta a poeira da tempestade que acaba de passar, acorrentando o fruidor a uma cena mórbida que procura acalanto no olhar do outro.

Palavras-chave: narrativa visual; cadeira; experiência.

\footnotetext{
1 Ver John Dewey, Arte como Experiência, 2010, p. 109.

2 'Ação de inventar', 'constante movimento de reinvenção'.
} 


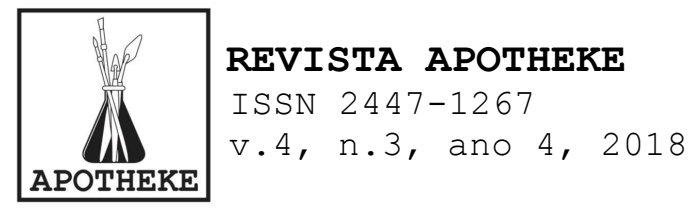

\section{Referências}

DEWEY, John. Arte como Experiência. São Paulo: Martins Fontes, 2010.

MARTINS, Raimundo; TOURINHO, Irene. Pesquisa narrativa: concepções, práticas e indagações. In: Anais do II Congresso de educação, arte e cultura - CEAC, Santa Maria, 2009, pp. 1-12. 